\section{Magic and Medicine in Early England}

DROF. CHARLES SINGER, professor of the history of medicine in the University of London, delivered the Fison Memorial Lecture in the anatomical theatre of Guy's Hospital Medical School on June 18. The subject of the lecture was "Magic and Medicine in Early England".

Prof. Singer pointed out that there must have been a mass of magico-medical material of combined Celtic and Roman, Pagan and Christian origin in use in England before the advent of the Anglo-Saxon culture. This early material has almost entirely disappeared; only faint traces of it have been recovered by folk-lorists in any recognisable form. Early Celtic elements have disappeared almost entirely even from the manuscript texts. Considering the labour that has been put into it for over a century, the results of folk-lore research in England are very disappointing and singularly destitute in positive results. Most so-called 'native' folk-lore is part of the general European heritage and strongly coloured by Roman civilisation and Roman Christianity. In so far as English folk-lore is medical, it is largely in line with and probably derived from the herb-lore of Salerno in southern Italy. That town, of mixed Latin, Greek and Saracen culture, was the purveyor of such material to Europe throughout the Middle Ages at least from the tenth century onward. The leech books that have come down to us from Anglo. Saxon times, however, whether in Latin or in the Anglo-Saxon language, contain a certain amount of material of distinctive character, some of which is of genuinely early and even of pagan origin. In these early leech books magical and simple herbal remedies are inextricably mixed. The Anglo-Saxon leech books are largely commonplace books in which, from time to time, supposedly useful recipes, both for men and beasts, were jotted down.

There has been some discussion as to who were the men who used, read and wrote these books. At least some of the leech books were certainly not produced nor could they have been used by priests. For the administration of many of the remedies, the prescriptions specifically state that a priest must be called in. Some few of the magical devices are of obviously pagan tone and it is most unlikely that they were either written or used by anyone in orders. There are a considerable number of representations of leeches in Anglo-Saxon art and these never show the tonsure. It is probable that the Anglo-Saxon leeches were men of the yeoman or farmer class who combined with their calling a hereditary knowledge of leechcraft much as was the case until quite modern times in certain families in Wales and the Gaelicspeaking highlands of Scotland.

There are in all about twenty manuscripts of Anglo-Saxon origin and of magico-medical interest. Practically all are in the libraries of the British Museum, the Bodleian and Corpus Christi College, Oxford and the preservation of most of them is due to the foresight exhibited in the sixteenth century by Sir Robert Cotton and Archbishop Parker.

As regards the actual remedies in the leech books, the overwhelming majority represent corrupted and misunderstood classical medicine of Greek origin from which, however, all rational elements and all theoretical considerations have almost wholly departed. A certain amount consist of direct translation of Salernitan material. Ecclesiastical elements are strong throughout and many remedies are suggested by or are modelled on the ceremonies of the Church. Wandering Syrian traders and Celtic missionaries or Italian priests must have been introduced, for tags of Irish, Byzantine and Syriac theurgy are traceable here and there. In several places a few words of Greek, Irish, Syriac and Hebrew are recognisable and a number of 'Pytha. gorean' charms have survived which use misunder. stood Greek letters. Among the strangest survivals of all is a Hebrew alphabet which accords to the Samaritan type, and is to be found in an Anglo. Saxon manuscript in Exeter Cathedral library.

The leech books provide evidence for some direct traffic in Anglo-Saxon times between south Italy and England. Apart from the Salernitan elements, there is evidence of direct copying of figures from that source. Some of the Anglo-Saxon leech books are handsomely illustrated by figures of plants, and it can be shown that many of these represent Mediterranean and not British forms. Again, a number of representations of the scorpion-a favourite theme in these manuscripts - are obviously copied from the work of artists who were familiar with this part of southern Europe.

Among the magical spells in the leech books are a few exhibiting pagan Saxon elements. In almost all of these there has been a systematic attempt to Christianise the original form. In one, however, of about 1100 or a little later, the name of the god Woden has been allowed to stand. Thus traces of an almost open paganism must have survived in England at least as late as the twelfth century.

Perhaps the most curious of all the pagan survivals, and one which lasted well into Norman times, is a group of Latin prayers addressed to the pagan classical 'Queen of Heaven'. Owing to the somewhat obscure wording this deity was evidently mistaken for the Virgin.

Despite the persistence and interest of these traces of paganism, there can be no doubt that pagan elements, whether classical Anglo-Saxon, Celtic or other are very few and unimportant. The material and spirit of the early English leech books are overwhelmingly Latin and Christian and all other ele. ments are obviously rapidly receding.

\section{Educational Topics and Events}

Cambridge.-The Anglo-American Corporation of South Africa, the Central Mining and Investment Corporation, the Consolidated Goldfields of South Africa, the New Consolidated Goldfields and the Union Corporation have each made a donation of $£ 1,000$ to the Cavendish Laboratory.

Miss G. L. Elles of Newnham College has been appointed reader in geology. R. F. Kahn of King's College has been appointed University lecturer in economics, C. W. Gilbert of Jesus College, University demonstrator in physics, Dr. E. C. Childs of Clare College, University demonstrator in soil science, C. H. Waddington of Christ's College, University lecturer in zoology, D. H. Valentine of St. John's College, University demonstrator in botany and Dr. G. A. Millikan of Trinity College, University lecturer in physiology. H. P. Whiting of Queens' College has been appointed assistant to the Director of the Museum of Zoology. 